\title{
Cadmium induced histopathological changes in the stomach and small intestine of Swiss albino mice Mus musculus
}

\author{
Animesh K. Mohapatra*, Poonam Kumari and Shivika Datta \\ Department of Zoology, Regional Institute of Education (NCERT), Ajmer-305004 (Rajasthan), INDIA \\ *Corresponding author. E-mail: akmrie01@yahoo.co.in
}

\begin{abstract}
The results on the effect of oral administration of cadmium chloride on the histomorphology of the stomach and small intestine of Swiss albino mice revealed severe histopathological effects in the tissues of both stomach and small intestine. There is marked atrophy of musculature, and disintegration of sub-mucosal and mucosal tissues, distortion of villi with disintegration of mucosal epithelial cells characterized by cytoplasmic vacuolization, nuclear pycnosis and nuclear fragmentation. A significant damage in the Brunner's gland and crypts of Liberkuhn has been observed.
\end{abstract}

Keywords: Cadmium chloride, Serosa, Musculature, Brunner's glands and Crypts of liberkuhn

\section{INTRODUCTION}

Environmental pollution by metals has become extensive as mining and industrial activities have increased in past few decades. Mine production includes $\mathrm{Cd}, \mathrm{Cu}, \mathrm{Pb}$ and $\mathrm{Hg}$ in considerable amounts (Kennish, 1996). These pollutants, which are derived from growing number of diverse anthropogenic sources, industrial effluents, urban run-off, sewage treatment plants, agricultural run off and domestic garbage dumps etc., have progressively affected more and more ecosystems (Wickfors and Ukeles, 1982; Rebhun and Amotz, 1984; Cotte-Krief et al., 2000; Bu-Olayan et. al., 2001; Macfarlane and Burchett, 2001; and Esser and Volpe, 2002).

Effects of heavy metals on various organs of animals have been studied by many scientists but mostly in invertebrates and lower vertebrates. However, there is a dearth of studies on the toxic effect of heavy metals on mammalian organs. Doreswamy et al. (2004) studied the effect of nickel on testicular histoarchitecture in mice. Sharma et al. (1980) in guinea pig and Yang et al. (2006) in rats showed that administration of cadmium chloride caused a decline in the weight of the body as well as of the testes, degeneration of germinal epithelium accompanied by nuclear pycnosis followed by cytolysis and nuclear fragmentation in the seminiferous tubules. Ingestion of heavy metal like lead induces impairment of proximal tubular function manifests in aminoaciduria, glycosuria and hyper-phosphaturia and death in animals (Mc Dowell, 1992; Gurer-Orhan and Ercal, 2000; Phetsombat et al., 2006 and Babu et al., 2007). Most of the studies on the effect of heavy metals are on the liver, kidney and gonads of mammals but no studies have been made on alimentary canal. The general aims of the present work were to estimate the impact of oral administration of cadmium on the stomach and small intestine.

\section{MATERIALS AND METHODS}

Adult Swiss albino mice of ten weeks old weighing about $37 \mathrm{~g}( \pm 3 \mathrm{~g})$ were kept in groups of six in polypropylene cages under standard conditions. They were maintained on commercial mice feed and had free access to water. The cages were housed under normal light and dark conditions in a controlled atmosphere with a temperature of $25^{\circ} \mathrm{C} \pm 5^{\circ} \mathrm{C}$ and a mean relative humidity of $50 \% \pm 5 \%$. To study the histopathological effects of cadmium, a single dose of cadmium chloride dissolved in distilled water (3gm per kg body weight) were administered orally to mice with the help of a micro-pipette. The control group was also maintained side by side and received equal volume of distilled water. Mice from both control and treated groups were scarified after 48 hours and 96 hours of post-treatment. The dissections were carried out in normal saline; stomach and small intestine were fixed in Bouin's fixative, dehydrated and embedded in paraffin wax. The blocks were sectioned at $5 \mu \mathrm{m}$ and the sections were stained by using hematoxylin and eosin.

\section{RESULTS}

Effects on stomach: Histological sections of stomach of control group mice showed normal histoarchitecture (Figs. 1, 2). The stomach wall is composed of same four basic layers as the rest of the GI tract. The surface of the mucosa is a layer of columnar epithelial cells and below which is present lamina propria. Epithelial cells extend down into the lamina propria to form columns of secretory cells called gastric glands. The submucosa is composed of areolar connective tissue. The musculature has an 


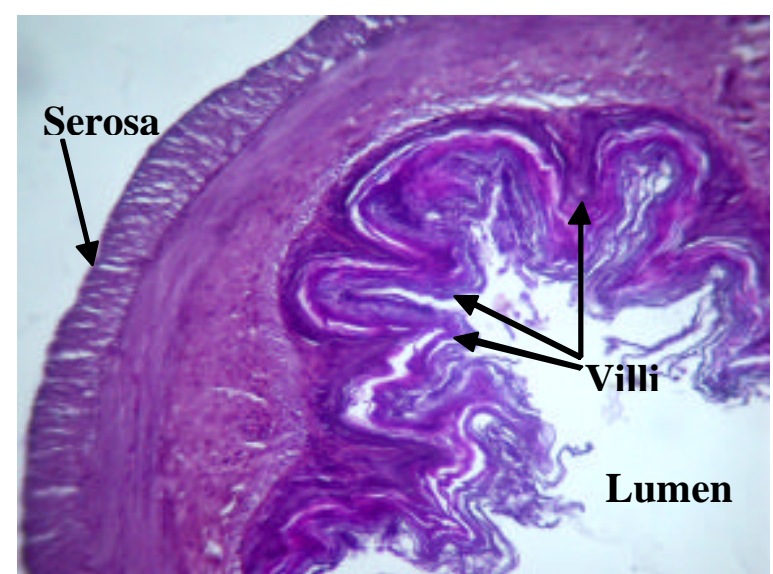

Fig. 1. Section of stomach of control mice showing normal histoarchitecture.

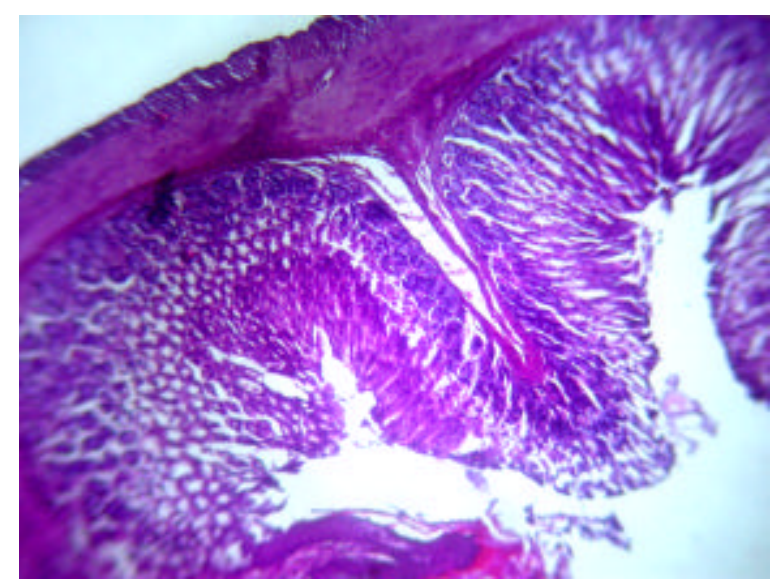

Fig. 3. Section of stomach of 48 hours post-treatment treated mice showing atrophy of musculature and disintegrated submucosa and mucosa.

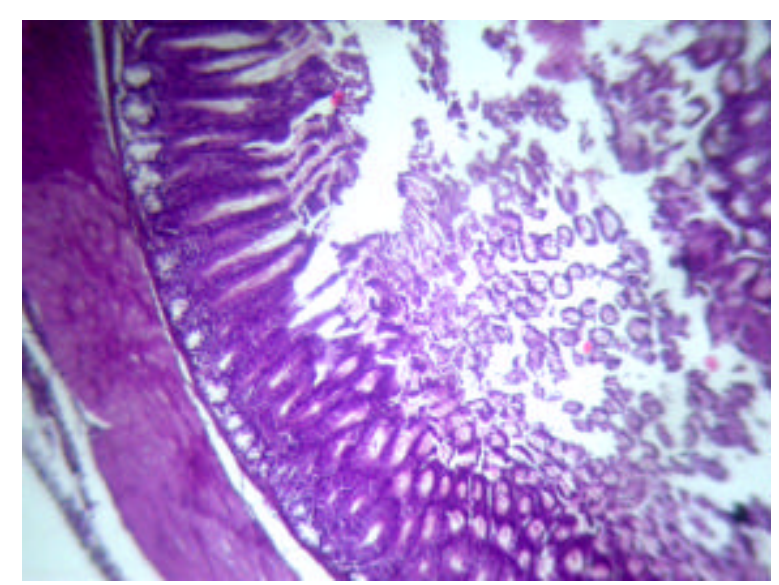

Fig. 5. Section of stomach of 96 hours post-treatment treated mice showing atrophy of musculature and disintegrated submucosa and mucosa.

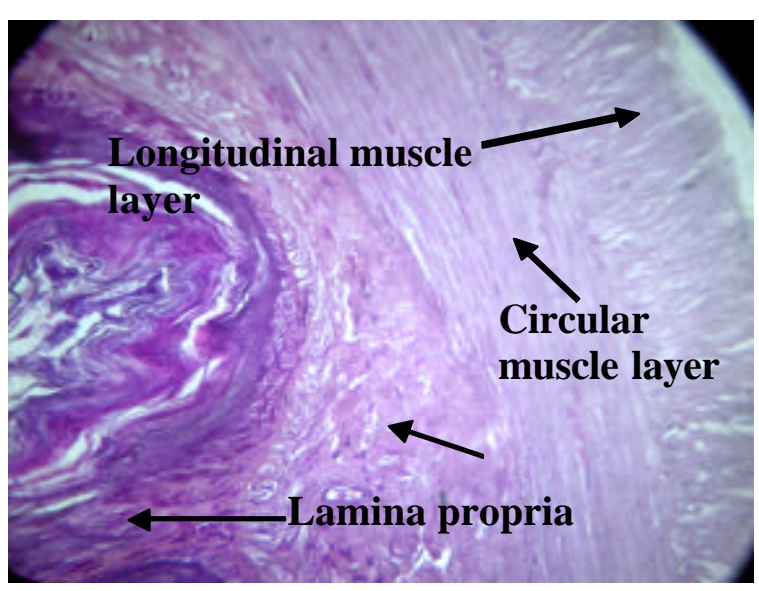

Fig. 2. Section of stomach of control mice showing normal musculature (M), submucosa (SM) and lamina propria (LP).

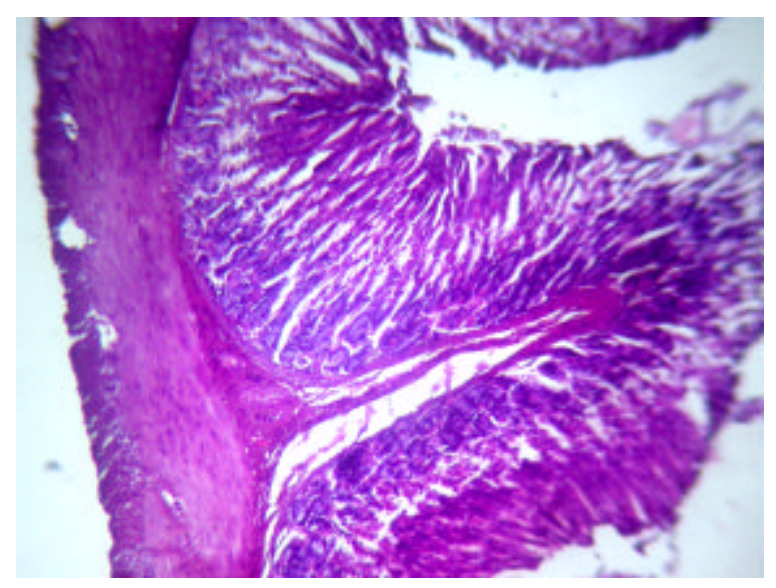

Fig. 4. Section of stomach of 48 hours post-treatment treated mice showing atrophy of LM and villi.

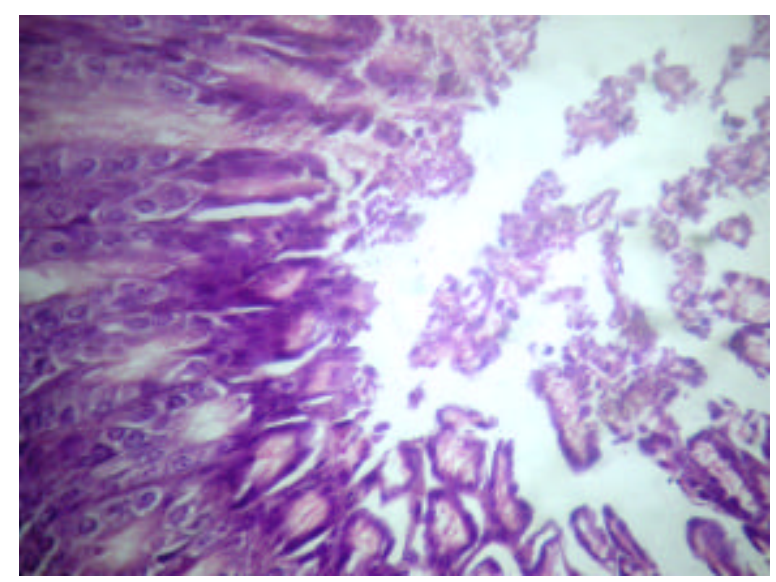

Fig. 6. Section of stomach of of 96 hours post-treatment treated mice showing cytoplasmic vacuolization and pycnotic nuclei in the mucosa epithelial cells. 


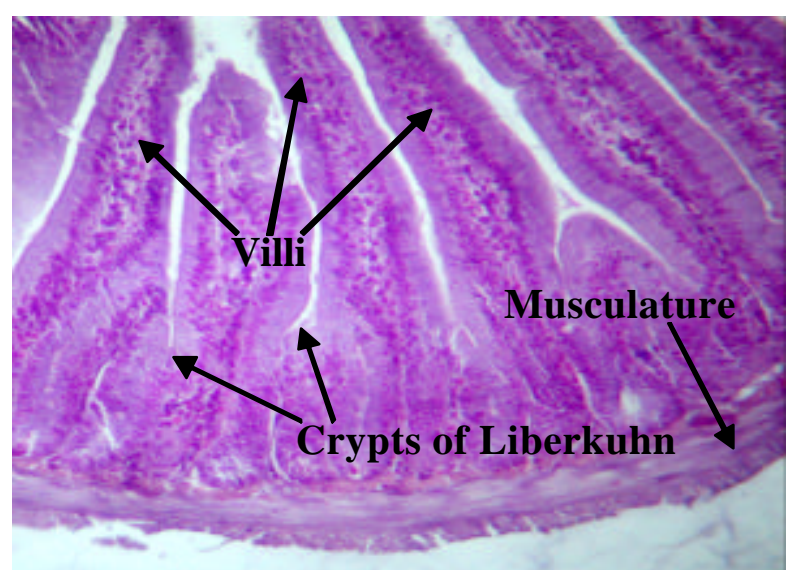

Fig. 7. Section of small intestine of control mice showing normal musculature $(M)$, villi and crypts of Liberkuhn $(L K)$.

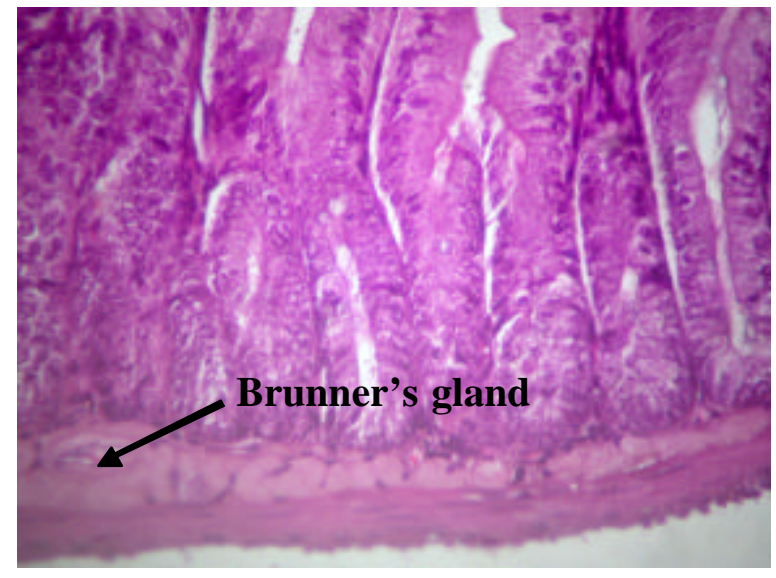

Fig. 9. Section of small intestine of 48 hours post-treatment treated mice showing atrophy of musculature and disintegrated sub- mucosa and mucosa.

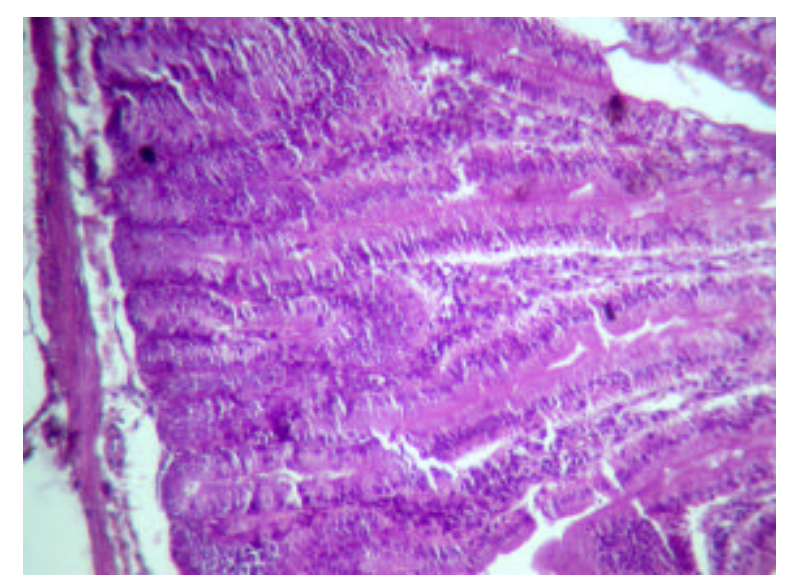

Fig. 11. Section of small intestine of 96 hours post-treatment treated mice showing atrophy of $M, S M$ and $L P$.

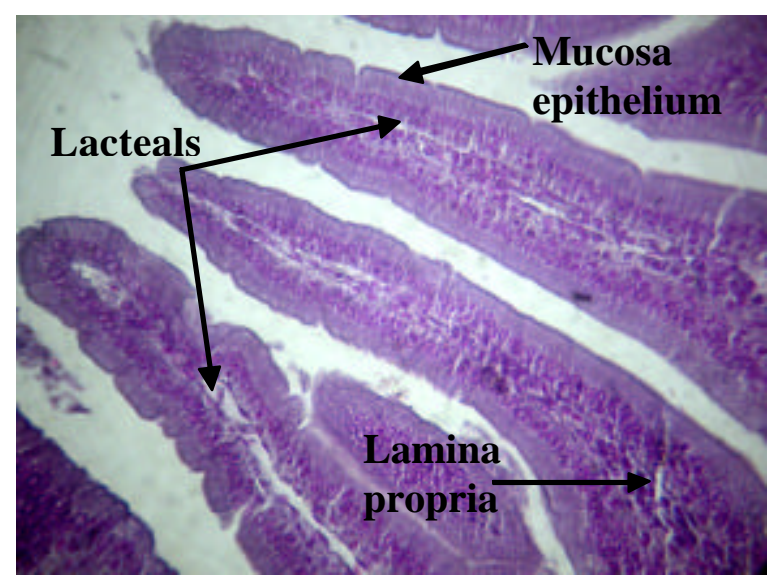

Fig. 8. Section of small intestine of control mice showing normal villi with lamina propria (LP), mucosa epithelium (ME) and lacteals.

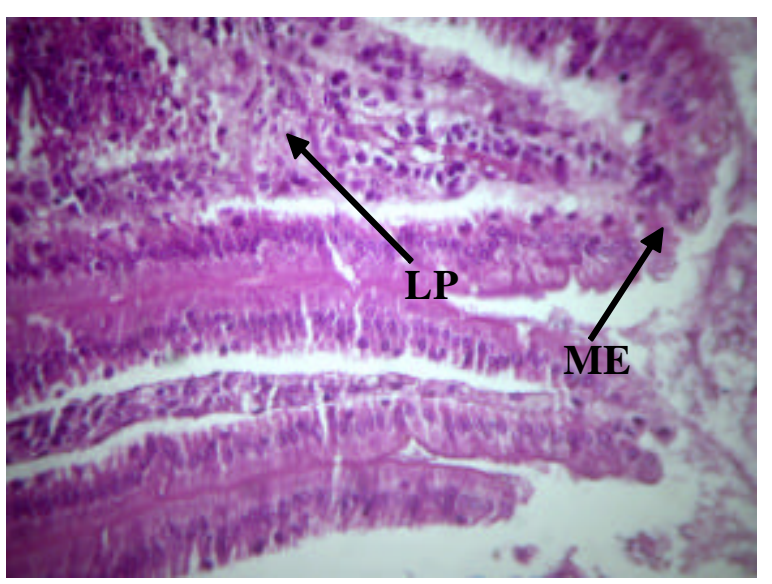

Fig. 10. Section of small intestine of 48 hours post-treatment treated mice showing atrophy of LM and ME.

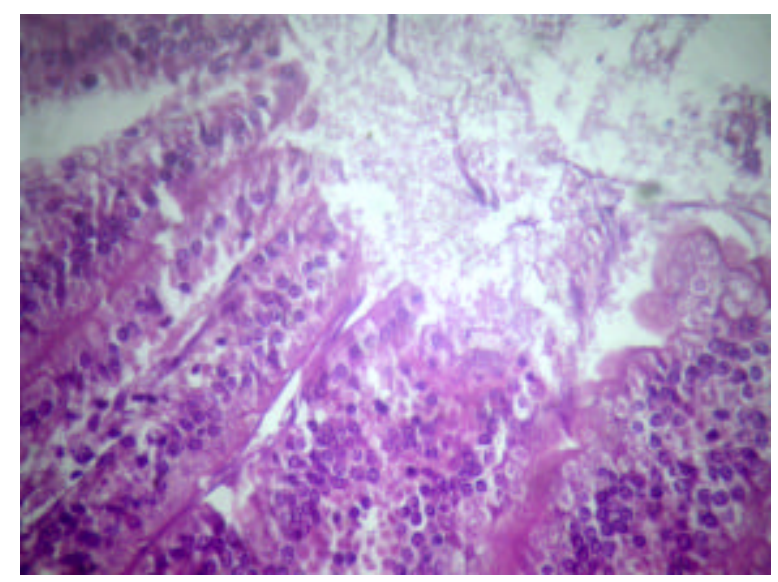

Fig. 12. Section of small intestine of 96 hours post-treatment treated mice showing disintegration LM, ME and vacuolization. 
outer longitudinal layer and inner layer of circular muscle fibres. The serosa is composed of simple squamous epithelium.

Marked histomorphological changes were observed in the stomach of treated mice (Figs. 3-6). In the treated mice there was significant decrease in the musculature. Both longitudinal and circular muscle layers exhibited atrophy. Significant disintegration of tissues of submucosa and mucosa were observed characterized by presence of irregular masses of tissues with spaces between them and light staining which is more pronounced in 96 hours post treatment mice (Figs. 5 and 6). Mucosa epithelial cells show cytoplasmic vacuolization and pycnotic nuclei.

Effects on small intestine: The small intestine of untreated mice has normal intestinal histoarchitecture (Figs. 7 and 8). The mucosa forms a series of finger like villi, each showing a core of lamina propria (areolar connective tissue), blood capillaries and a lacteal. The simple columnar mucosal epithelium contains absorptive goblet, enteroendocrine and paneth cells. Crypts of Liberkuhn in the mucosa and Brunner's glands in the sub mucosa were observed. The musculature showed an outer thinner longitudinal and inner thicker circular layer of muscle fibres.

Severe histopathological changes were observed in treated mice (Figs. 9-12). Atrophy of musculature was observed to different extent in 48 hours to 96 hours posttreatment mice (Figs. 10, 12). At many places serosa is disrupted and separated from musculature. Areolar connective tissue of the submucosa and mucosa showed atrophy which was more pronounced in 96 hours posttreatment mice (Fig. 11). It is characterized by irregular masses of tissues, separated by small to large irregular spaces and paler staining. Distortions of villi were prominent in both categories of treated mice. Absorptive, goblet, enteroendocrine and paneth cells of columnar epithelium including the cells of Brunner's gland appear paler due to cytoplasmic disruption leading to formation of numerous vacuoles. The nuclei of these cells showed disintegration indicated by the presence of clumped nuclear material (Fig. 12).

\section{DISCUSSION}

There have been numerous reports on the toxic effects of heavy metals on multiple organs in different animals. Few of these studies are on mammalian tissues. The histopathological alterations induced by different heavy metals in the tissues of testis, liver and renal organs have been reported by Elbetieha and Al-hamood (1977), Sharma et al. (1980), Kwon et al. (1997), Bataineh et al. (1998), Mayyas et al.(2005), Yang et al. (2006) and Garba et al. (2007). There have been no reports on the alteration of histoarchitecture in the gut of animals in response to heavy metal toxicity. In the present study it was observed that oral administration of $\mathrm{CdCl}_{2}$ resulted in significant histopathological abnormalities in the stomach and small intestine as evident by the atrophy of musculature, disintegration of sub-mucosal and mucosal areolar connective tissue and disruption of serosa to different extent in 48 hours to 96 hours post-treatment mice. The mucosa epithelial cells showed cytoplasmic vacuolization, paler staining, necrotic nuclei indicated by the presence of clumped nuclear material and in many nuclear pycnosis in both 48 hours and 96 hours post-treatment mice. Perusal of literature shows no information regarding heavy metal toxicity on the gut wall in any animal. The present study is probably first of its kind. Similar effects of heavy metals on the tissues of testis, liver and kidney have been reported by Saksena and Lau (1979), Bataineh et al. (1998), and Mayyaset al. (2005) in testis; Karmaker et al. (2000) in liver and Garba et al. (2007) in renal organs. Mechanism for the cytoplasmic vacuolization has been given by Robbins and Angell (1976) as one of the important responses to all forms of cell injury. Disturbances in lipid inclusions and fat metabolism in response to toxic substances result in cytoplasmic vacuolization (Zhang and Wang, 1984). The result of the present study revealed that heavy metal cadmium also affects gut wall in the same manner as on other tissues.

\section{ACKNOWLEDGEMENT}

The authors wish to express their deep sense of gratitude to Prof. V. G. Jadhao, Principal for his constant encouragement and providing all facilities to carryout the study. We are thankful to Mr. Manoj Kumar, Laboratory Assistant, Zoology department for his untiring help.

\section{REFERENCES}

Babu, S. M., Venu Gopal, N. and Pratap R. K. (2007). Post natal antioxidant enzyme activity of rat brain regions during developmental lead exposure. J. Environ. Biol., 28, 21-27.

Bataineh, H., Al-Hamood, M. and Elbetieha, A. (1998). Assessment of aggression, sexual behaviour and fertility in adult male rat following long-term ingestion of four industrial metal salts. J. Human Exp. Toxicol., 17: 570-576.

Bu-Olayan, A. H., Al-Hassan, R., Thomas, B. V. and Subhrmanyam, M.N.V. (2001). Impact of trace metal sand nutrient levels on phytoplanktons from the Kuwait coast. Environ. Int., 26: 199-203.

Cotte-Krief. M.C., Guiea, C., Thomas, A. J. and Martin, J. M. (2000). Sources of Cd, Cu, Ni and $\mathrm{Zn}$ in Portuguese coastal waters. Mar. Chem., 71: 199-214.

Doreswamy, K., Balakrishna, S., Thimappa, R. and Muralidhara, K. (2004). Nickel induced oxidative stress in testis of mice: Evidence of DNA damage and genotoxic effects. Journal of Andrology, 25 (6) November/December 2004.

Elbetieha, A., Al-Hamood, M. (1997). Term exposure of male and female mice to trivalent and hexavalent chromium 
compounds. Effect on fertility. J. toxicol., 116: 39-47.

Esser, B. K. and Volpe, A. (2002). At sea high-resolution trace element mapping: San Diego bay and its plume in adjacent coastal ocean. Environ. Sci. Technol., 36: 2826-32.

Garba, S. H., Adelaiye, A. B. and Mshelia, L.Y. (2007). Toxicological Effects of Inhaled Mosquito Coil Smoke on the Rat Spleen: A Hematological and Histological study. $J$. Med. Sci., 7 (1): 94-99.

Gurer Orhan, H. and Ercal, N. (2000). Can antioxidants beneficial in the treatment of lead poising. Free radical Biol. Med., 29, 927-945.

Karmakar, R., Bhattacharya, R. and Chatterjee, M. (2000) Biochemical, hematological and histopathological study in relation to time-related cadmium induced hepatotoxicity in mice. Biometals, 13 (3): 231-239.

Kennish, M. J. (1996). Practical Handbook of Estuarine and Marine Pollution. CRC Press, New York, 535pp.

Kwon K. S., Cho, K. J. and Yang, E. J. (1997). The study of anatomical and biochemical effects of cadmium on the testis in rats. Dev. Reprod., 1: 125-132.

Macfarlane, G. R. and Burchett, M. D. (2001). Photosynthetic pigments and peroxidase activity as indicators of heavy metal stress in the grey mangrove,Avicennia marina (Forsk). Viesh. Mar. Pollut. Bull., 42: 233-40.

Mayyas, I., Elbetieha, A., Khamas, W. and Khamas, W. A. (2005). Evaluation of reproductive and fertility toxic potentials of aluminium chloride on adult male mice.J. Anim. Vet. Adv., 4: 224-233.
McDowell, L.S. (1992). Minerals in Animal and human nutrition. Academic Press Inc. California, 361-364.

Phetsombat, S., Maleeya, K., Pokethitiyook, P. and Upatham, S. (2006). Toxicity and bioaccumulation of cadmium and lead in Salvinia cucullata. L. J. Environ. Biol., 27, 645-652. Rebhun, S. and Amotz, A. B. (1984). The distribution of cadmium between the marine algae Chlorella stigmatophora and sea water medium. Water Res., 18: 173-178.

Robbins, S. and Angell, D. (1976). Basic Pathology, $2^{\text {nd }}$ Ed, W. B. Saunders Company, Philadelphia, London.

Saksena, S. and Lau, I. (1979). Effects of cadmium chloride on testicular steroidogenesis and fertility of male rats. $J$. Endocrinol., 74: 6-12.

Sharma, G. P., Sareen, M. L. and Monga, V. K. (1980). Effect of cadmium chloride on the testis of the Guinea pig, Cavia cobaya. Proc. Nat. Agad. Sci. India, 50 (B), III.

Wickfors, G. H. and Ukeles, R. (1982). Growth and adaptation of estuarine unicellular algae in media with excess copper, cadmium and zinc. Mar. Ecol. Progr. Ser., 191-206.

Yang. H. S., Dong Kein, H., Jung Ran, K. and Jae Chul Sim (2006). Effects of $\alpha$-tocopherol on cadmium induced toxicity in rat testis and spermatogenesis. Journal of Korean Medical Science. 21 (3) 445-451.

Zhang, L.Y. and Wang, C.X. (1984). Histopathological and histochemical studies on toxic effect of brodifacoum in mouse liver. Acta Acad Med Sci., 6 (5) :386-388. 